\title{
Coupling of the atmosphere and sediment melts across the Archean-Proterozoic transition
}

Janne Liebmann ( $\nabla$ janne.liebmann@postgrad.curtin.edu.au )

Curtin University

Christopher Spencer

Queen's University

Christopher Kirkland

Curtin University

Claire Bucholz

California Institute of Technology

Xiao-Ping Xia

Guangzhou Institute of Geochemistry, Chinese Academy of Sciences

Laure Martin

University of Western Australia

Nami Kitchen

California Institute of Technology

Leonid Shumlyanskyy

Curtin University

\section{Article}

Keywords: Great Oxygenation Event, sulfur isotopes, oxygen isotopes, Earth system

Posted Date: August 17th, 2020

DOI: https://doi.org/10.21203/rs.3.rs-55162/v1

License: (c) (i) This work is licensed under a Creative Commons Attribution 4.0 International License.

Read Full License 


\section{Abstract}

The Archean-Proterozoic transition marks a time of fundamental geologic, biologic, and atmospheric changes to the Earth system, including oxygenation of the atmosphere (termed the Great Oxygenation Event; GOE), and the emergence of continents above sea-level. The impacts of the GOE on Earth's surface environment are imprinted on the geologic record, including the attenuation of mass-independent fractionation of sulfur isotopes (S-MIF). Temporally overlapping geologic and geochemical observations (e.g. a change in oxygen isotope ratio of sediment melts) imply the widespread subaerial emergence of continents was coeval with atmospheric oxygenation. Here we present triple sulfur isotope ratios in pyrite and oxygen isotope ratios in garnet and zircon in a global suite of Archean and Proterozoic sedimentderived granitoids. These crustal melts record an increase in average 180/160 isotope ratio and a disappearance of S-MIF in the Paleoproterozoic. The coupled behaviour of sulfur and oxygen isotope signatures imply a potential causal link between the emergence of continents and atmospheric oxygenation at $\sim 2.3 \mathrm{Ga}$.

\section{Introduction}

The oxygenation of the Earth's atmosphere and oceans irreversibly changed many major biogeochemical cycles (e.g. Fe, S, Mn) ${ }^{1}$ and provided the base for a highly efficient aerobic metabolism that allowed the development of complex life ${ }^{2}$. During the Great Oxygenation Event (GOE) (c. 2.3 Ga) atmospheric oxygen increased from $<0.001 \%$ of the present atmospheric level (PAL) ${ }^{3}$ to $10-40 \%$ PAL ${ }^{4}$, or perhaps much higher approaching $100 \% \mathrm{PAL}$, and references therein. The mechanism that led to atmospheric oxygenation remains controversial. Proposed scenarios for oxygenation include 1) an increase in $\mathrm{O}_{2}$ production (i.e. through the emergence of oxygenic photosynthesis) ${ }^{6}, 2$ ) a decrease in $\mathrm{O}_{2}$ consumption (e.g. through changing redox state of volcanic gases, increased burial of organic carbon, or decreased pyrite weathering) 7,8 , and 3 ) a combination of both processes (through enhanced oxygenic photosynthesis combined with increased carbon burial) ${ }^{9}$. One source of dispute is the timing of the invention of oxygenic photosynthesis; suggestions range from $>3.7 \mathrm{Ga}{ }^{10}$ to immediately preceding atmospheric oxygenation ${ }^{6}$. Previous studies imply that the widespread emergence of continents above sea-level is temporally correlated with atmospheric oxygenation ${ }^{11}$. Furthermore, it has been proposed that the subaerial emergence of continents may have led to a flux of life-essential nutrients into the ocean supporting a boost in photosynthetic activity ${ }^{12}$.

Multiple sulfur isotopic signatures are a sensitive tracer for atmospheric oxygen levels ${ }^{13}$. Some sulfides and sulfates in metasedimentary rocks deposited prior to the GOE display mass-independent fractionation of sulfur (S-MIF), whereas those deposited after the GOE display almost wholly massdependent fractionation (S-MDF) ${ }^{13,14}$. It has been postulated that S-MIF was generated in the atmosphere through ultraviolet photolysis of gas molecules ${ }^{15}$. The establishment of an ozone shield as a consequence of atmospheric oxygenation led to blocking of UV radiation and attenuation of the 
photolysis of volcanic sulfur species ${ }^{13}$. In addition, enhanced oxidative weathering of sulfides and the formation of oceanic sulfates stimulated the activity of sulfur-metabolizing bacteria supporting the generation of S-MDF signatures ${ }^{16}$. Recent studies show that fluctuations in atmospheric oxygen level are also captured in the igneous rock record; namely, through recycling of S-MIF in the crust ${ }^{17,18}$, and a change in oxygen fugacity of strongly peraluminous granites ${ }^{19}$.

Broadly coeval with atmospheric oxygenation, the average oxygen isotope ratio of global felsic magmas (recorded by zircon $\delta^{18} 0$ ) increases ${ }^{20}$. The oxygen isotopic composition of a magma is sensitive to the recycling of supracrustal material ${ }^{21}$. Igneous zircon in high-temperature equilibrium with the mantle has remarkably homogenous $\mathrm{d}^{18} \mathrm{O}$ values which average $5.3 \pm 0.6 \%{ }^{22}$ relative to standard mean ocean water (VSMOW). Supracrustal material (e.g. sedimentary and volcanic rocks), in contrast, has a wide range of $d^{18} 0$ values ( 0-40\%o) with most reservoirs being elevated in $d^{18} 0$ relative to the mantle ${ }^{23}$. Hence, assimilation of supracrustal material commonly results in magmas with elevated $\mathrm{d}^{18} \mathrm{O}$ compared to primitive mantle-derived magmas. An increase in average $\delta^{18} \mathrm{O}$ of zircon in the Paleoproterozoic has been recognized for over a decade ${ }^{20}$. Contrasting models have been suggested to account for this increase in $\left.\delta^{18} 0 ; 1\right)$ the formation of high $\delta^{18} 0$ sediments (and sediment-derived melts) potentially linked to enhanced subaerial weathering and erosion related to the emergence of continents above sea-level 24,25 , and 2) enhanced crustal recycling associated with the onset of collisional tectonics ${ }^{26}$. However, high- $\delta^{18} \mathrm{O}$ sediment melts do not show a concomitant depletion in radiogenic ${ }^{176} \mathrm{Hf}$, as would be expected if the increase in $\delta^{18} \mathrm{O}$ was related to enhanced supracrustal recycling ${ }^{25}$. Therefore, a change in sediment oxygen isotope composition potentially associated with the subaerial emergence of continents seems to be the likely driver for the Paleoproterozoic increase in average zircon $\delta^{18} \mathrm{O}^{25}$.

We explore a potential link between the emergence of continents above sea-level and atmospheric oxygenation through a coupled analysis of proxies for atmospheric oxygen level and sedimentary recycling in Archean to Mesoproterozoic sediment-derived granitoids (i.e. granitoids that partially or wholly derive from the partial melting of metasediments). Here we present pyrite multiple sulfur isotope ratios in tandem with zircon and garnet oxygen isotope ratios for a global sample set. The combination of these proxies allows us to provide new insights into the coupled behaviour of geodynamic, biogenic, and atmospheric evolution.

\section{Results}

\section{Bulk-rock geochemistry and mineralogy}

Samples include granitoids comprised of quartz + alkali feldspar + plagioclase \pm biotite in varying proportions, and contain one or more peraluminous indicator minerals, such as garnet or muscovite. The samples for which bulk-rock geochemical data is available are strongly peraluminous with an aluminium saturation index $(\mathrm{ASI}) \geq 1.1$ (defined as molecular $\mathrm{Al} /[\mathrm{Ca}-1.67 \mathrm{P}+\mathrm{Na}+\mathrm{K}]$ ). For comparison ACNK values (defined as molecular Al/[Ca $+\mathrm{Na}+\mathrm{K}]$ ) are also reported in Table 2. With the exception of sample 15K-2, 
ASI and ACNK yield identical values to the first decimal place. The mineralogy of all samples is summarized in Table 1. Bulk rock major element concentrations are given in Table 2. Thin section photomicrographs can be found in supplementary Figure A4.

\section{Geochronology}

Magmatic crystallization ages of the 30 sediment-derived granitoids in this study are Neoarchean to Mesoproterozoic, ranging from $2664 \pm 45 \mathrm{Ma}$ to $1447 \pm 50 \mathrm{Ma}$. For nine of these samples the magmatic crystallization age was determined in this study (as zircon concordia, upper intercept, or weighted mean ${ }^{207} \mathrm{~Pb}^{\star} /{ }^{206} \mathrm{~Pb}^{\star}$ ages). For nine samples zircon U-Pb SIMS ages were determined in previous studies ${ }^{25}$. For the remaining 12 samples for which no or only metamict zircon was extracted, preferred ages use robust published dates from the same batholith or are estimates based on the age of proximal magmatism. A detailed description of the geochronology is given in Appendix A; a summary is given in Table 3. Single-spot zircon U-Pb results can be found in supplementary Table B1.

\section{Zircon and garnet oxygen isotope geochemistry}

Zircon $\delta^{18} \mathrm{O}$ values range from $4.93 \pm 0.82 \%$ o to $11.41 \pm 1.00 \%$ o. Similarly, garnet $\delta^{18} \mathrm{O}$ values range from $7.06 \pm 0.09 \%$ o to $11.50 \pm 0.12 \%$ o. Note, that no garnet was extracted from the two samples with the lowest zircon $\delta^{18} \mathrm{O}$ values $(19 \mathrm{GH}$, and $19 \mathrm{GH} 11 \mathrm{~B})$. Zircon records a lower range of $\delta^{18} \mathrm{O}$ values for samples with crystallization ages $>2.3 \mathrm{Ga}(2 \sigma=0.5 \%$, number of samples $=3)$ as compared to samples with crystallization ages $<2.3 \mathrm{Ga}(2 \sigma=4.1 \%, \mathrm{n}=12)$, whereas the range of garnet $\delta^{18} 0$ stays approximately the same ( $>2.3 \mathrm{Ga}$ garnet: $2 \sigma=1.2 \%, \mathrm{n}=10 ;<2.3 \mathrm{Ga}$ garnet: $2 \sigma=1.1 \% \mathrm{o}, \mathrm{n}=10)$. On average $\delta^{18} \mathrm{O}$ values increase post- $2.3 \mathrm{Ga}$; from $7.15 \%$ o to $9.08 \%$ in zircon, from $7.22 \%$ o to $10.24 \%$ o in garnet, and from $7.19 \%$ o to $9.30 \%$ combining the data of both zircon and garnet. Equilibrium fractionation of oxygen isotopes between zircon and almandine-rich garnet is small at temperatures typical for granitoid melts $\left(<0.1 \%\right.$ o at temperatures $\left.>650^{\circ} \mathrm{C}\right){ }^{27}$. The garnet-zircon pairs of all samples indicate oxygen isotopic equilibrium (Figure 1). Two samples (17FIN02 and 17FIN04A) yield heterogeneous single spot zircon $\delta^{18} 0$ values $\left(2 \sigma>3 \%\right.$ ) and are interpreted to reflect secondary signatures ${ }^{28}$. This is further supported by $\mathrm{CL}$ images revealing that some areas in some zircon grains are affected by metamictization (supplementary Figure A2). Therefore, the oxygen isotopic composition recorded by garnet from these two samples provides the best estimate of their parental magma $\delta^{18} \mathrm{O}$. Data tables with single spot 0 isotopic data are given in the supplementary Table D1, a summary of weighted means is given in Table 3.

\section{Sulfur isotope geochemistry}

Pyrite grains are euhedral to sub-euhedral, chemically homogenous, and largely free of inclusions and intergrown phases. BSE images of representative pyrite grains for each sample are given in the supplementary Figure A3. Pyrite $\delta^{34} S$ values range from $-13.33 \pm 0.36 \%$ o to $9.72 \pm 0.99 \%$, but are mostly (11 out of 13 samples) between $-4 \%$ and $4 \%$. Single spot pyrite $\delta^{34} S$ and $\Delta^{33} S$ values cluster tightly around discrete values for each sample, and seemingly define single populations (Figure 2). Four 
samples show pyrite $\Delta^{33} \mathrm{~S}$ outside of the S-MDF range (Figure 2). These samples include three $\sim 2.7 \mathrm{Ga}$ granites from the Superior province that exhibit positive $\Delta^{33} \mathrm{~S}$ values of $0.13 \pm 0.06 \%$ o to $0.18 \pm 0.05 \%$, and a $\sim 2.5 \mathrm{Ga}$ granite from the North China Craton with negative $\Delta^{33} \mathrm{~S}$ value of $-0.29 \pm 0.12 \%$. Data tables with single spot sulfur isotopic data are given in the supplementary Table $\mathrm{C} 1$, a summary of weighted means is given in Table 3.

\section{Discussion}

The presence of aluminous mineral phases and/or ASI $\geq 1.1$ strongly suggest that the studied granitoids were derived from the partial melting of metasedimentary protoliths ${ }^{29,30}$. The partial or entire derivation of these granitoids from metasedimentary protoliths is in accord with previous interpretations of the regional geology ${ }^{31-34}$. Zircon and garnet tend to preserve a record of the oxygen isotope composition of their parental melt due to slow intracrystalline diffusion rates of oxygen in these minerals ${ }^{35,36}$. Given the small equilibrium fractionation (smaller than the analytical uncertainty) of oxygen isotopes between almandine-rich garnet and zircon at temperatures typical for granitoid melts ${ }^{27}$ (Figure 1) $\delta^{18} 0$ values recorded by garnet and zircon, respectively, in the sediment-derived granitoids of this study are directly comparable. The range and average $\delta^{18} \mathrm{O}$ values of sediment-melts increases post-2.3 Ga (Figure 3), in accord with previous studies that interpret the rise of average $\delta^{18} 0$ to be the result of continental emergence and a concomitant change in sediment composition ${ }^{24,25}$. Low $\delta^{18} \mathrm{O}$ values in sediment melts (equal or lower than the mantle value of $5.3 \pm 0.6 \%$; ${ }^{22}$, like in $19 \mathrm{GH} 9$ and $19 \mathrm{GH} 11 \mathrm{~B}$, are interpreted to reflect hydrothermal alteration of the protolith ${ }^{37}$. It has been proposed that interaction of a melt with hydrothermal meteoric water - a mechanism that requires emergent land area - may be the process responsible for such low $\delta^{18} \mathrm{O}$ melts ${ }^{37}$. The emergence of continents at $\sim 2.4 \mathrm{Ga}$ is supported by changes to geochemical proxies at this time, such as an increase in seawater ${ }^{87} \mathrm{Sr} /{ }^{86} \mathrm{Sr}{ }^{38}$, a decrease in shale $\Delta^{17} \mathrm{O}^{24,39}$, as well as an increase in subaerial large igneous province volcanism ${ }^{11}$.

Pyrite-bearing sediment-derived granitoids with crystallization ages $>2.3 \mathrm{Ga}$ yield non-zero $\Delta^{33} \mathrm{~S}$ values, whereas those younger than $2.3 \mathrm{Ga}$ uniformly show $\Delta^{33} \mathrm{~S}$ of $0 \%$. Although the $\Delta^{33} \mathrm{~S}$ values of the $>2.3$ Ga granitoids are small compared to those in pre-GOE sedimentary rocks (up to $\sim 12 \%$ ) ${ }^{14}$, the magnitude of non-zero $\Delta^{33} S$ values observed here is too large to be the result of S-MDF processes alone (Figure 2). Hence, the S-MIF signatures in the $>2.3$ Ga pyrite-bearing granitoids record the recycling of sedimentary sulfur species formed under the anoxic pre-GOE atmosphere, as has been demonstrated for S-MIF carrying strongly peraluminous granites in previous studies ${ }^{18}$. Three of the $>2.3 \mathrm{Ga}$ granitoids of this study show positive $\Delta^{33} \mathrm{~S}$ values, one sample shows a negative $\Delta^{33} \mathrm{~S}$ value. The pre-GOE pyrite record is skewed towards positive $\Delta^{33}$ S values ${ }^{14}$. Positive $\Delta^{33}$ S anomalies are commonly found in Archean sedimentary pyrite that may have formed from reduced sulfur species (e.g. $\mathrm{S}_{8}$ aerosols) produced through photodissociation in the oxygen-poor atmosphere ${ }^{13,40}$. Based on the dominance of negative $\Delta^{33} \mathrm{~S}$ values in Archean barites, it has been posited that oceanic sulfates (formed from oxidized sulfur 
species produced through photodissociation; e.g. $\mathrm{SO}_{4}$ aerosols) carry the complementary negative $\Delta^{33} \mathrm{~S}$ signatures required by isotopic mass balance ${ }^{13}$. However, recent studies report positive $\Delta^{33} \mathrm{~S}$ anomalies in Archean oceanic sulfate ${ }^{41}$. The inconsistent sulfur isotopic budget is a yet unsolved scientific problem, and the complementary negative $\Delta^{33} \mathrm{~S}$ reservoir remains cryptic.

The low $\delta^{34} S$ value ( -13\%) of pyrite in sample SP-17-43 from the Wenasaga Lake batholith, Superior province, could derive from the contribution of organic sulfur. Mircobial sulfate reduction commonly produces sulfides that are strongly depleted in the heavy ${ }^{34} \mathrm{~S}$ isotope ${ }^{42}$. The S-MIF signature in this sample $\left(\Delta^{33} S=0.16 \pm 0.04 \%\right.$ ) indicates atmospheric influence. Therefore, the recorded sulfur isotopic composition of this sample may be the result of mixing between two reservoirs (i.e. atmospheric and microbial sulfur). A similar scenario has been suggested to be responsible for the negative $\delta^{34} S$ values and positive $\Delta^{33} S$ values of pyrite in the upper Mount McRae shale in the Hamersley Basin, Western Australia ${ }^{43}$. Alternatively, the low $\delta^{34} S$ value in this sample could arise during fractionation between $S^{2-}$ in the melt and $\mathrm{H}_{2} \mathrm{~S}$ in a vapor phase (produced through metamorphic devolatilization) as documented for other samples from the Superior Craton ${ }^{18}$.

The youngest sediment-derived granitoid of this study that shows S-MIF and oxygen isotopic signatures respectively implying an anoxic atmosphere and widely submerged continents (sample 18IM19) has a crystallization age of $2478 \pm 18 \mathrm{Ma}$. The oldest sample (19GH11B) showing only S-MDF and O isotopic signatures indicating respectively an oxygenized atmosphere and emergent continents yields a crystallization age of $2188 \pm 20 \mathrm{Ma}$. The evolution of oxygen and sulfur isotopic signatures appear to be coupled in the samples of this study. However, the data is inconclusive for the $300 \mathrm{Myr}$ interval between the youngest S-MIF and the oldest S-MDF sample. The preserved rock record between 2.4 and $2.2 \mathrm{Ga}$ is sparse 44,45 making it challenging to fill this temporal gap. If the evolution of sulfur and oxygen isotopic signatures in sediment-derived melts is truly coupled, this would provide strong evidence for a temporal, and potentially causal connection of the emergence of continents and atmospheric oxygenation.

According to Warke et al. (2020) ${ }^{46}$ atmospheric oxygenation preceded widespread, potentially global, glaciations. This conclusion is based on sedimentary formations on the Fennoscandian shield, in which the transition from S-MIF to S-MDF-bearing strata occurs below the diamictite member of the formations linked to Makganyene glaciation ${ }^{46}$. This temporal relationship between atmospheric oxygenation and widespread glaciations rules out models in which Proterozoic ice houses facilitated the invention of oxygenic photosynthesis 47 , and hence, calls for an alternative driver for the rise of $\mathrm{O}_{2}$. Numerical models demonstrate the strong influence of subaerial continental emergence on phosphorous fluxes to the oceans ${ }^{12}$. Elevated, emerged continental crust and associated enhanced erosion would increase the supply of life-essential nutrients into the ocean, increasing that available for oxyphotobacteria ${ }^{9,12}$. It has been suggested that a similar mechanism involving the erosion of elevated continental crust has initiated the explosive radiation of animal-life during the Late Ediacaran to Early Cambrian periods (575-510 Ma; 'Cambrian explosion') ${ }^{48}$. A flush of nutrients associated with enhanced erosion may have led to an 
increase in $\mathrm{O}_{2}$ production and provided a favourable environment for the explosive diversification of life 49. Similarly, an increased nutrient flux (e.g. phosphorous) to the oceans associated with the Paleoproterozoic subaerial emergence of continents may have fuelled a boost in oxygenic photosynthesis (either in terms of radiation or bioproductivity) ${ }^{50}$. A shift in ocean nutrient availability from phosphorous to iron limiting may have resulted in ecological conditions favourable for oxygenic photoautotrophs over anoxygenic photoautotrophs ${ }^{51}$. Furthermore, increased erosion and sediment supply from the elevated continents would facilitate the burial of organic carbon leading to diminished $\mathrm{O}_{2}$ consumption ${ }^{9}$.

Potential causes of the Paleoproterozoic subaerial emergence of continents are a 2.4-2.2 Ga tectonomagmatic slowdown ${ }^{44,45}$, or the effect of dynamic topography ${ }^{52}$ during the $\sim 2.45 \mathrm{Ga}$ rifting of Superior 53 . The proposed $\sim 2.4-2.2$ Ga lull in mantle activity and concomitant reduced plate-velocities ${ }^{44}$ and midocean ridge activity ${ }^{54}$ could have led to cooling and thickening of the oceanic lithosphere causing subsidence of the ocean floor and a drop in eustatic sea-level ${ }^{54,55}$. Mantle upwelling during the $\sim 2.45 \mathrm{Ga}$ rifting of Superior ${ }^{53}$ and associated dynamic topography would likely have led to continental uplift and high freeboard ${ }^{52}$.

The implication of our study is that the subaerial emergence of continents constitutes a potential driver for ecological changes that fuelled oxygenic photosynthesis, ultimately leading to a change in redox state of the Earth's atmosphere and oceans.

\section{Materials And Methods}

\section{Sample context}

Samples of this study derive from various localities within the Superior, North China, West African, and East European Cratons, and the Yavapai province (USA). A list of all samples including location is given in Table 1.

\section{Superior Craton}

The Superior Craton forms the Archean core of the Canadian Shield and can be divided into the Western and Eastern Superior Province, which are further subdivided into 17 distinct tectonic terranes ${ }^{31}$. (Meta-)granitoid- and greenstone-dominated terranes evolved independently from 3.7-2.75 Ga, followed by accretionary events associated with the trapping of sedimentary basins and high-temperature metamorphism, leading to the formation of a coherent Superior Craton by $2.60 \mathrm{Ga}^{31}$. Peraluminous granites are widespread within the Superior Craton, and their occurrence is described in detail by ${ }^{56}$.

\section{North China Craton}


The North China Craton comprises Archean to Paleoproterozoic basement overlain by Mesoproterozoic to Cenozoic cover sequences ${ }^{32}$. Recent publications subdivide the Precambrian basement of this region into three tectonic domains; Archean to Proterozoic Western and Eastern Blocks and a central Paleoproterozoic collisional Trans-North China Orogen ${ }^{32}$. The Western Block comprises the Yinshan Block in the north and the Ordos Block in the south. The Neoarchean Yinshan Block comprises tonalitetrondhjemite-granodiorite (TTG) gneisses and minor supracrustal rocks that were metamorphosed at $\sim 2.5 \mathrm{Ga}^{57}$.

\section{Baoulé-Mossi domain, West African Craton}

The Paleoproterozoic ( 2.3-2.0 Ga) Baoulé-Mossi domain in the southern portion of the West African Craton comprises sedimentary basins and volcanic/volcaniclastic rocks that are intruded by multiple generations of granitic rock ${ }^{33}$, and references therein . The emplacement of felsic intrusions across the BaouléMossi domain is associated with the 2.2-1.8 Eburnean Orogeny ${ }^{58}$. No agreement has been reached upon the tectonic model for the Paleoproterozoic evolution. Proposed scenarios include plume-related, subduction-related, and continental collision-related models ${ }^{33}$, and references therein.

\section{Ukrainian Shield, East European Craton}

The Ukrainian Shield is a region of exposed Archean and Proterozoic crust within Samartia in the southwestern part of the East European Craton. The Ukrainian Shield is comprised by several tectonic blocks separated by suture zones described in detail by ${ }^{59}$. High grade metamorphism and associated magmatism occurred in multiple domains of the Ukrainian Shield at $\sim 2.8$ and 2.1-2.0 Ga and may reflect an active-margin setting ${ }^{59}$.

\section{Svecofennian domain, Baltic Shield, East European Craton}

The Svecofennian Orogeny in Finland between 1.91 and $1.87 \mathrm{Ga}$ involved accretion of island arc complexes and older crustal fragments to the Archean basement of the Karelian Craton ${ }^{34}$. In southernmost Finland, 2.0-1.8 Ga old crust was intruded by sediment-derived granites at 1.84-1.83 Ga associated with high-temperature, low-pressure granulite facies metamorphism and migmatization 60 . This complex, referred to as the late Svecofennian granite-migmatite zone, includes the Sulkava, West Uusuma, and Turku areas ${ }^{61}$. Granitic material is abundant in the Turku area. Mostly, these magmas occur as garnet and cordierite bearing leucosome in magmatic metapelites ${ }^{34}$.

\section{Yavapai province}

The Yavapai province (or Colorado province) south of the Wyoming Craton comprises 1.79-1.66 Ga volcanic-plutonic suites and sediments that are interpreted to have formed in a convergent margin setting 62. These rocks experienced multiple deformational episodes associated with metamorphism and 
plutonism between 1.71 and $1.62 \mathrm{Ga}$ described in detail by Hoffman, (1988). The deformational episodes were followed by two pulses of calc-alkaline to alkaline magmatism at $1.50-1.42 \mathrm{Ga}$ and $1.40-1.34 \mathrm{Ga}{ }^{63}$. 


\begin{tabular}{|c|c|c|c|c|c|c|}
\hline 17FIN01 & $\begin{array}{l}\text { Svecofennian } \\
\text { domain }\end{array}$ & 60.498 & 22.262 & Grt migmatite & $\mathrm{Grt}+\mathrm{Qz}+\mathrm{Afs}+\mathrm{Pl}+\mathrm{Bt}$ & this study \\
\hline 17FIN02 & $\begin{array}{l}\text { Svecofennian } \\
\text { domain }\end{array}$ & 60.470 & 22.368 & Grt migmatite & $\mathrm{Grt}+\mathrm{Qz}+\mathrm{Afs}+\mathrm{Pl}+\mathrm{Bt}$ & this study \\
\hline 17FIN03B & $\begin{array}{l}\text { Svecofennian } \\
\text { domain }\end{array}$ & 60.425 & 22.382 & Grt migmatite & $\mathrm{Grt}+\mathrm{Qz}+\mathrm{Afs}+\mathrm{Pl}+\mathrm{Bt}$ & this study \\
\hline 17FIN04A & $\begin{array}{l}\text { Svecofennian } \\
\text { domain }\end{array}$ & 60.461 & 22.176 & Grt migmatite & $\mathrm{Grt}+\mathrm{Qz}+\mathrm{Afs}+\mathrm{Pl}+\mathrm{Bt}$ & this study \\
\hline 17FIN05B & $\begin{array}{l}\text { Svecofennian } \\
\text { domain }\end{array}$ & 60.546 & 22.128 & Grt migmatite & $\mathrm{Grt}+\mathrm{Qz}+\mathrm{Afs}+\mathrm{Pl}+\mathrm{Bt}$ & this study \\
\hline 17FIN06 & $\begin{array}{l}\text { Svecofennian } \\
\text { domain }\end{array}$ & 60.482 & 22.018 & Grt migmatite & $\mathrm{Grt}+\mathrm{Qz}+\mathrm{Afs}+\mathrm{Pl}+\mathrm{Bt}$ & this study \\
\hline 19GH11B & $\begin{array}{l}\text { West African } \\
\text { Craton }\end{array}$ & -1.609 & 5.140 & Bt Ms granite & $\mathrm{Ms}+\mathrm{Qz}+\mathrm{Afs}+\mathrm{Pl}+\mathrm{Bt}$ & this study \\
\hline 19GH9 & $\begin{array}{l}\text { West African } \\
\text { Craton }\end{array}$ & -1.377 & 5.340 & Bt Ms granite & $\mathrm{Ms}+\mathrm{Qz}+\mathrm{Afs}+\mathrm{Pl}+\mathrm{Bt}$ & this study \\
\hline 19GH3 & $\begin{array}{l}\text { West African } \\
\text { Craton }\end{array}$ & -1.156 & 5.160 & Grt granite & $\mathrm{Grt}+\mathrm{Qz}+\mathrm{Afs}+\mathrm{Pl}+\mathrm{Bt}$ & this study \\
\hline $18 \mathrm{IM} 19$ & $\begin{array}{l}\text { North China } \\
\text { Craton }\end{array}$ & 40.693 & 109.641 & Grt granite & $\mathrm{Grt}+\mathrm{Qz}+\mathrm{Afs}+\mathrm{Pl}+\mathrm{Bt}$ & $\begin{array}{l}\text { Liebmann } \\
\text { et al. } \\
2020 a\end{array}$ \\
\hline 18IM20 & $\begin{array}{l}\text { North China } \\
\text { Craton }\end{array}$ & 40.709 & 109.643 & Grt granitoid & $\mathrm{Grt}+\mathrm{Qz}+\mathrm{Afs}+\mathrm{Pl}+\mathrm{Bt}$ & $\begin{array}{l}\text { Liebmann } \\
\text { et al. } \\
2020 a\end{array}$ \\
\hline 18IM23D & $\begin{array}{l}\text { North China } \\
\text { Craton }\end{array}$ & 40.811 & 110.258 & Grt granite & $\mathrm{Grt}+\mathrm{Qz}+\mathrm{Afs}+\mathrm{Pl}$ & $\begin{array}{l}\text { Liebmann } \\
\text { et al. } \\
2020 a\end{array}$ \\
\hline 18IM25C & $\begin{array}{l}\text { North China } \\
\text { Craton }\end{array}$ & 41.182 & 109.479 & Ms Bt granite & $\mathrm{Ms}+\mathrm{Qz}+\mathrm{Afs}+\mathrm{Pl}(+\mathrm{Bt})$ & $\begin{array}{l}\text { Liebmann } \\
\text { et al. } \\
2020 \text { a }\end{array}$ \\
\hline 18IM11B & $\begin{array}{l}\text { North China } \\
\text { Craton }\end{array}$ & 40.604 & 112.500 & Grt granitoid & $\mathrm{Grt}+\mathrm{Qz}+\mathrm{Afs}+\mathrm{Pl}+\mathrm{Bt}$ & $\begin{array}{l}\text { Liebmann } \\
\text { et al. } \\
2020 a\end{array}$ \\
\hline 18IM12B & $\begin{array}{l}\text { North China } \\
\text { Craton }\end{array}$ & 40.839 & 112.565 & $\begin{array}{l}\text { Grt quartz } \\
\text { rich granitoid }\end{array}$ & $\mathrm{Grt}+\mathrm{Qz}+\mathrm{Afs}+\mathrm{Pl}$ & $\begin{array}{l}\text { Liebmann } \\
\text { et al. } \\
2020 a\end{array}$ \\
\hline 18IM13C & $\begin{array}{l}\text { North China } \\
\text { Craton }\end{array}$ & 41.084 & 110.924 & Grt granite & $\mathrm{Grt}+\mathrm{Qz}+\mathrm{Afs}+\mathrm{Pl}+\mathrm{Bt}(+\mathrm{Ms})$ & $\begin{array}{l}\text { Liebmann } \\
\text { et al. } \\
2020 \text { a }\end{array}$ \\
\hline 18IM15B & $\begin{array}{l}\text { North China } \\
\text { Craton }\end{array}$ & 40.994 & 110.947 & Grt granitoid & $\mathrm{Grt}+\mathrm{Qz}+\mathrm{Afs}+\mathrm{Pl}$ & $\begin{array}{l}\text { Liebmann } \\
\text { et al. } \\
2020 a\end{array}$ \\
\hline 18IM3 & $\begin{array}{l}\text { North China } \\
\text { Craton }\end{array}$ & 40.848 & 113.921 & Grt granite & $\mathrm{Grt}+\mathrm{Ms}+\mathrm{Qz}+\mathrm{Afs}+\mathrm{Pl}(+\mathrm{Bt})$ & $\begin{array}{l}\text { Liebmann } \\
\text { et al. } \\
2020 a\end{array}$ \\
\hline $15 \mathrm{~K}-2$ & $\begin{array}{l}\text { Ukrainian } \\
\text { Shield }\end{array}$ & 50.980 & 28.680 & Granite & $\mathrm{Qz}+\mathrm{Pl}+\mathrm{Bt}$ & this study \\
\hline $\mathrm{CO}-17-8$ & $\begin{array}{l}\text { Yavapai } \\
\text { province }\end{array}$ & 39.776 & 105.780 & Bt Ms granite & $\mathrm{Ms}+\mathrm{Qz}+\mathrm{Afs}+\mathrm{Pl}+\mathrm{Bt}$ & $\begin{array}{l}\text { Bucholz } \\
\text { and } \\
\text { Spencer, } \\
2019\end{array}$ \\
\hline SP-16-20a & $\begin{array}{l}\text { Superior } \\
\text { Craton }\end{array}$ & 49.815 & 93.020 & Bt Ms granite & $\mathrm{Ms}+\mathrm{Qz}+\mathrm{Afs}+\mathrm{Pl}+\mathrm{Bt}$ & $\begin{array}{l}\text { Bucholz } \\
\text { et al. } \\
2018\end{array}$ \\
\hline SP-16-2b & Superior & 47.661 & 92.939 & $\begin{array}{l}\text { Bt Ms granite } \\
\text { age } 10 / 23\end{array}$ & $\mathrm{Ms}+\mathrm{Qz}+\mathrm{Afs}+\mathrm{Pl}+\mathrm{Bt}$ & Bucholz \\
\hline
\end{tabular}


Superior Craton

$\begin{array}{cc}\text { SP-16-34 } & \begin{array}{c}\text { Superior } \\ \text { Craton }\end{array} \\ \text { SP-17-43 } & \begin{array}{c}\text { Superior } \\ \text { Craton }\end{array} \\ \text { SP-17-33 } & \begin{array}{c}\text { Superior } \\ \text { Craton }\end{array} \\ \text { SP-17-38 } & \begin{array}{c}\text { Superior } \\ \text { Craton }\end{array} \\ & \end{array}$

SP-17-82

Superior
Craton

SP-17-71

SP-17-13

SP-17-50
Craton

Table 1. Summary
accessory phases.

Mineral abbreviations: Qz, quartz; Afs, alkali feldspar; PI, plagioclase; Grt, garnet; Ms, muscovite, Bt, biotite. and $\begin{array}{ll}\text { Ms Grt } & \text { Spencer, } \\ \text { granite } & \text { Grt+Ms+Qz+Afs+Pl } \\ 2019\end{array}$

\begin{tabular}{|c|c|c|c|c|c|}
\hline & 50.994 & 92.328 & $\begin{array}{l}\text { Ms Grt } \\
\text { granite }\end{array}$ & $\mathrm{Grt}+\mathrm{Ms}+\mathrm{Qz}+\mathrm{Afs}+\mathrm{Pl}$ & $\begin{array}{l}\text { Spencer, } \\
2019\end{array}$ \\
\hline $\begin{array}{l}\text { Superior } \\
\text { Craton }\end{array}$ & 48.906 & 89.213 & Bt Grt qranite & $\mathrm{Grt}+\mathrm{Oz}+\mathrm{Afs}+\mathrm{Pl}+\mathrm{Bt}$ & this study \\
\hline $\begin{array}{l}\text { Superior } \\
\text { Craton }\end{array}$ & 50.847 & 92.105 & $\begin{array}{l}\text { Bt Ms Grt } \\
\text { granite }\end{array}$ & $\mathrm{Grt}+\mathrm{Ms}+\mathrm{Qz}+\mathrm{Afs}+\mathrm{Pl}+\mathrm{Bt}$ & this study \\
\hline
\end{tabular}

Bucholz et al. 2018 Bt Ms Grt Bt Ms Grt $\mathrm{Ms}+\mathrm{Qz}+\mathrm{Grt}+\mathrm{Afs}+\mathrm{Pl}+\mathrm{Bt}$ granite $\mathrm{Ms}+\mathrm{Qz}+\mathrm{Grt}+\mathrm{Afs}+\mathrm{Pl}+\mathrm{Bt}$ this study

$50.741 \quad 93.209$

\begin{tabular}{|c|c|c|}
\hline 50.284 & 94.495 & Bt Grt granite \\
\hline
\end{tabular}
Grt+Bt+Qz+Afs+Pl this study $49.863 \quad 93.771$ granite $\mathrm{Grt}+\mathrm{Ms}+\mathrm{Qz}+\mathrm{Afs}+\mathrm{Pl}$ this study Bucholz and Spencer, Ms Grt $51.200 \quad 92.383$ granite $\mathrm{Grt}+\mathrm{Ms}+\mathrm{Qz}+\mathrm{Afs}+\mathrm{Pl}$ 2019 Bucholz 
Sample Major element concentrations (reported as oxide wt \%)

ID $\mathrm{SiO}_{2} \mathrm{TiO}_{2} \mathrm{Al}_{2} \mathrm{O}_{3} \mathrm{Fe}_{2} \mathrm{O}_{3} \mathrm{MgO} \mathrm{CaO} \mathrm{Na} \mathrm{O} \mathrm{K}_{2} \mathrm{O} \mathrm{P}_{2} \mathrm{O}_{5} \mathrm{MnO}$ LOI Total ASIACNK

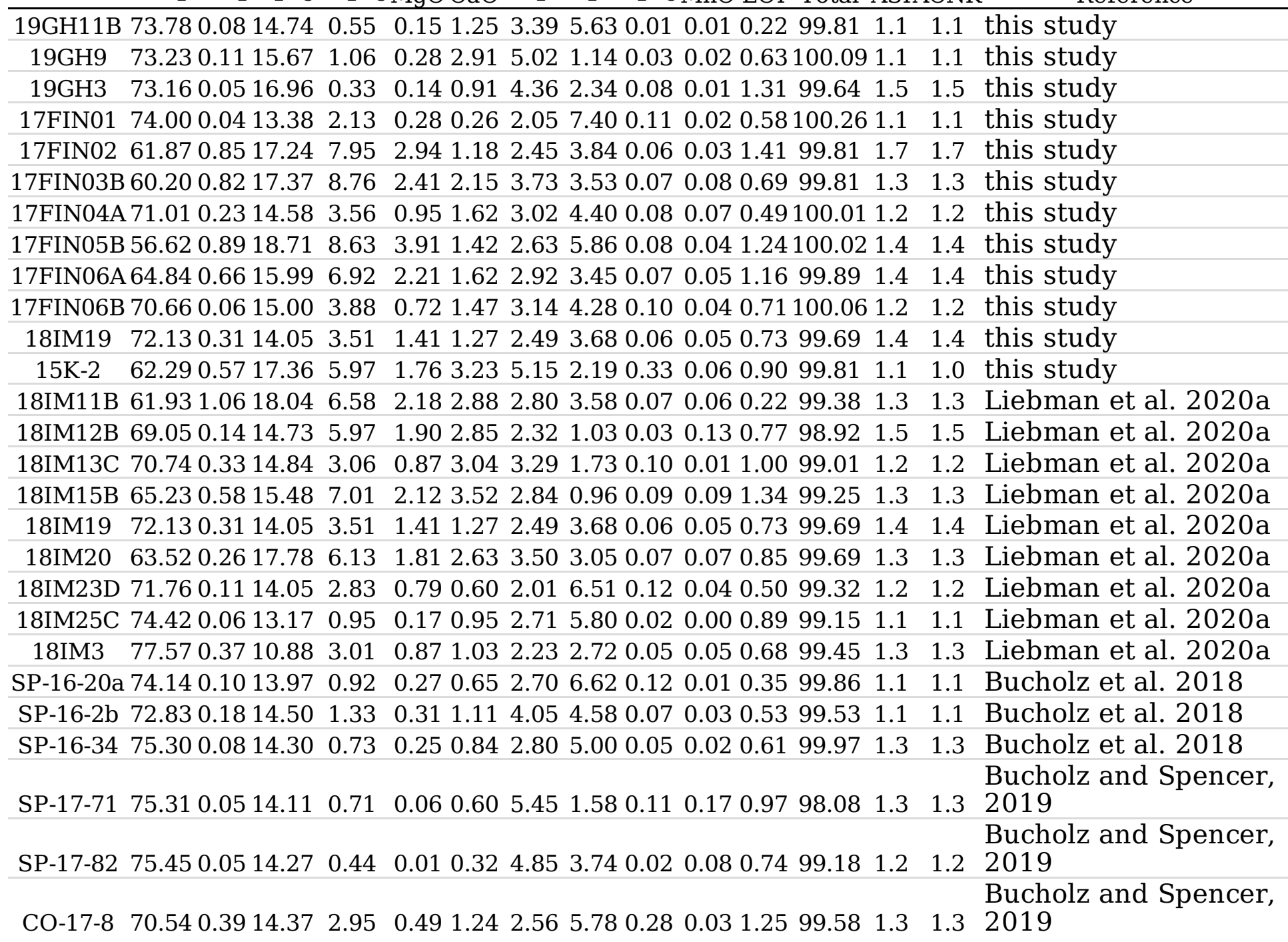

Table 2: Bulk rock major element concentrations. The aluminium saturation index (ASI) is calculated as molecular $\mathrm{Al} /(\mathrm{Ca}-1.67 \mathrm{P}+\mathrm{Na}+\mathrm{K})$; $\mathrm{ACNK}$ is calculated as molecular $\mathrm{Al} /(\mathrm{Ca}+\mathrm{Na}+\mathrm{K})$. 


\begin{tabular}{|c|c|c|c|c|c|c|c|c|c|c|}
\hline \multirow{3}{*}{$\begin{array}{l}\text { Sample } \\
\text { ID }\end{array}$} & \multirow[t]{3}{*}{ Locality } & \multirow{3}{*}{$\begin{array}{c}\text { Age } \pm 2 \sigma \\
\mathrm{Ma}\end{array}$} & \multicolumn{2}{|c|}{ zircon } & \multicolumn{2}{|c|}{ garnet } & \multicolumn{3}{|c|}{ pyrite } & \multirow[t]{3}{*}{ Reference } \\
\hline & & & $\delta^{18} \mathrm{O}$ & & $\delta^{18} \mathrm{O}$ & & $\delta^{34} S$ & & $\Delta^{33} S$ & \\
\hline & & & {$[\%$} & $2 \sigma$ & {$[\%$} & $2 \sigma$ & {$[\%$ o } & $2 \sigma$ & {$[\%$ o } & \\
\hline 17FIN01 & $\begin{array}{l}\text { Svecofennian } \\
\text { domain }\end{array}$ & $1850^{1)}$ & - & - & 10.39 & 0.20 & 1.54 & 0.99 & -0.01 & 0.08 this study \\
\hline 17FIN02 & $\begin{array}{l}\text { Svecofennian } \\
\text { domain }\end{array}$ & $\begin{array}{c}1896 \pm \\
26\end{array}$ & 8.78 & 3.22 & 9.87 & 0.24 & $=-0.87$ & 0.90 & -0.02 & 0.07 this study \\
\hline 17FIN03B & $\begin{array}{l}\text { Svecofennian } \\
\text { domain }\end{array}$ & $\begin{array}{c}1824 \pm \\
13\end{array}$ & 9.32 & 1.16 & 9.48 & 0.51 & -0.09 & 0.88 & 0.01 & 0.08 this study \\
\hline 17FIN04A & $\begin{array}{l}\text { Svecofennian } \\
\text { domain }\end{array}$ & $1850^{1)}$ & 10.37 & 3.46 & 10.02 & 0.10 & 0.85 & 1.41 & 0.01 & 0.06 this study \\
\hline 17FIN05B & $\begin{array}{l}\text { Svecofennian } \\
\text { domain }\end{array}$ & $\begin{array}{c}1836 \pm \\
11\end{array}$ & 10.52 & 0.77 & 10.30 & 0.11 & 1.61 & 0.55 & -0.01 & 0.06 this study \\
\hline 17FIN06 & $\begin{array}{l}\text { Svecofennian } \\
\text { domain }\end{array}$ & $\begin{array}{c}1815 \pm \\
16\end{array}$ & 10.20 & 0.61 & 10.28 & 0.11 & 1.58 & 0.93 & -0.01 & 0.07 this study \\
\hline 19GH11B & $\begin{array}{l}\text { West African } \\
\text { Craton }\end{array}$ & $\begin{array}{c}2188 \pm \\
20\end{array}$ & 5.34 & 0.83 & - & - & -3.71 & 1.51 & -0.05 & 0.07 this study \\
\hline $15 \mathrm{~K}-2$ & Ukrainian Shield & $\begin{array}{c}2144 \pm \\
28\end{array}$ & 8.86 & 0.81 & - & - & 9.72 & 0.99 & -0.04 & 0.06 this study \\
\hline CO-17-8 & Yavapai procinve & $\begin{array}{c}1447 \pm \\
50\end{array}$ & 8.74 & 0.61 & - & - & 3.31 & 0.26 & -0.02 & 0.05 this study \\
\hline SP-16-20a & Superior Craton & $\begin{array}{l}2654 \pm \\
24\end{array}$ & - & - & - & - & 0.60 & 0.56 & 0.13 & 0.06 this study \\
\hline SP-16-2b & Superior Craton & $\begin{array}{c}2664 \pm \\
45\end{array}$ & - & - & - & - & 1.79 & 0.61 & 0.18 & 0.05 this study \\
\hline SP-17-43 & Superior Craton & $2690^{2)}$ & - & - & 7.06 & 0.09 & -13.33 & 0.36 & 0.16 & 0.04 this study \\
\hline 18IM19 & $\begin{array}{l}\text { North China } \\
\text { Craton }\end{array}$ & $\begin{array}{l}2478 \pm \\
18\end{array}$ & 7.21 & 0.58 & 7.50 & 0.41 & -1.26 & 1.29 & -0.29 & $\begin{array}{l}\text { this study, Liebmann et } \\
0.12 \text { al. } 2020 \mathrm{a}\end{array}$ \\
\hline 18IM20 & $\begin{array}{l}\text { North China } \\
\text { Craton }\end{array}$ & $\begin{array}{c}2374 \pm \\
48\end{array}$ & 7.39 & 0.70 & 7.22 & 0.05 & - & - & - & $\begin{array}{l}\text { this study, Liebmann et } \\
\text { - al. 2020a }\end{array}$ \\
\hline 18IM11B & $\begin{array}{l}\text { North China } \\
\text { Craton }\end{array}$ & $\begin{array}{c}1901 \pm \\
17\end{array}$ & 10.8 & 0.90 & 10.77 & 0.14 & - & - & - & $\begin{array}{l}\text { this study, Liebmann et } \\
\text { - al. 2020a }\end{array}$ \\
\hline 18IM12B & $\begin{array}{l}\text { North China } \\
\text { Craton }\end{array}$ & $\begin{array}{c}1929 \pm \\
29\end{array}$ & 9.74 & 1.16 & 10.05 & 0.12 & - & - & - & $\begin{array}{l}\text { this study, Liebmann et } \\
\text { - al. 2020a }\end{array}$ \\
\hline 18IM3 & $\begin{array}{l}\text { North China } \\
\text { Craton }\end{array}$ & $\begin{array}{c}1917 \pm \\
70\end{array}$ & 11.41 & 1.00 & 11.52 & 0.12 & - & - & - & $\begin{array}{l}\text { this study, Liebmann et } \\
\text { - al. 2020a }\end{array}$ \\
\hline 18IM25C & $\begin{array}{l}\text { North China } \\
\text { Craton }\end{array}$ & $\begin{array}{c}2493 \pm \\
28\end{array}$ & 6.86 & 0.89 & - & - & - & - & - & $\begin{array}{l}\text { this study, Liebmann et } \\
\text { - al. 2020a }\end{array}$ \\
\hline 18IM13C & $\begin{array}{l}\text { North China } \\
\text { Craton }\end{array}$ & $\begin{array}{c}2536 \pm \\
13\end{array}$ & 8.12 & 0.70 & - & - & - & - & - & - Liebmann et al. 2020a \\
\hline 18IM15B & $\begin{array}{l}\text { North China } \\
\text { Craton }\end{array}$ & $\begin{array}{c}2530 \pm \\
60\end{array}$ & 8.57 & 0.42 & - & - & - & - & - & - Liebmann et al. 2020a \\
\hline 18IM23D & $\begin{array}{l}\text { North China } \\
\text { Craton }\end{array}$ & $\begin{array}{c}2453 \pm \\
11\end{array}$ & 6.31 & 0.63 & - & - & - & - & - & - Liebmann et al. 2020a \\
\hline 19GH9 & $\begin{array}{l}\text { West African } \\
\text { Craton }\end{array}$ & $\begin{array}{c}2183 \pm \\
14\end{array}$ & 4.93 & 0.82 & - & - & - & - & - & - this study \\
\hline 19GH3 & $\begin{array}{l}\text { West African } \\
\text { Craton }\end{array}$ & $2180^{1)}$ & - & - & 9.72 & 0.09 & - & - & - & - this study \\
\hline SP-16-34 & Superior Craton & $\begin{array}{c}2654 \pm \\
24\end{array}$ & - & - & 7.99 & 0.10 & - & - & - & - this study \\
\hline SP-17-33 & Superior Craton & $2650^{1)}$ & - & - & 7.85 & 0.13 & - & - & - & - this study \\
\hline SP-17-38 & Superior Craton & $2650^{1)}$ & - & - & 6.93 & 0.11 & - & - & - & - this study \\
\hline SP-17-82 & Superior Craton & $2650^{1)}$ & - & - & 6.06 & 0.12 & - & - & - & - this study \\
\hline SP-17-71 & Superior Craton & $2650^{1)}$ & - & - & 6.92 & 0.09 & - & - & - & - this study \\
\hline SP-17-13 & Superior Craton & $\begin{array}{c}2660 \pm \\
10^{3)}\end{array}$ & - & - & 7.15 & 0.10 & - & - & - & - this study \\
\hline
\end{tabular}


SP-17-50 Superior Craton $2650^{1)} \quad$ - $\quad$ - $\quad 7.550 .09 \quad-\quad$ - $\quad$ - $\quad$ - this study

Table 3. Summary of $\mathrm{O}$ and $\mathrm{S}$ geochemistry, and crystallization ages. Isotopic data is given as weighted average. ${ }^{1)}$ expected age (see appendix $\left.A\right),{ }^{2)}$ age from ${ }^{87},{ }^{3)}$ age from ${ }^{88}$.

\section{Declarations}

\section{A}

Supplementary Information (pdf file), including supplementary information on geochronology, supplementary Figures A1-A6, and supplementary Tables A1-A4.

\section{B}

Supplementary Table B1 (spread sheet), zircon U-Pb data.

C

Supplementary Table C1 (spread sheet), pyrite S isotope data.

D

Supplementary Table D1 (spread sheet), zircon and garnet O isotope data.

\section{Author contributions}

JL, CJS, CLK, CEB designed the research or contributed to designing the research. JL, CJS, CEB, LS collected the samples. JL, CLK, CEB, XPX, LM, NK carried out the analyses. JL, CJS, CLK, CEB contributed to interpreting the results. $\mathrm{JL}$ wrote the manuscript. All authors provided comments on the manuscript.

\section{Acknowledgements}

U-Pb geochronology analytical work at the John de Laeter Centre, Western Australia was enabled by NCRIS via AuScope. Oxygen and sulfur isotope analytical work at the Guangzhou Institute of Geochemistry was supported by the open fund from the State Key Laboratory of Isotope Geochemistry, GIGCAS (SKLabIG-KF-18-04). The authors acknowledge the facilities, and the scientific and technical assistance of Microscopy Australia at the Centre for Microscopy, Characterisation \& Analysis, The University of Western Australia, a facility funded by the University, State and Commonwealth Governments. 


\section{References}

1. Pufahl, P. K. \& Hiatt, E. E. Oxygenation of the Earth's atmosphere-ocean system: A review of physical and chemical sedimentologic responses. Mar. Pet. Geol. 32, 1-20 (2012).

2. Catling, D. C., Glein, C. R., Zahnle, K. J. \& McKay, C. P. Why O 2 Is Required by Complex Life on Habitable Planets and the Concept of Planetary 'Oxygenation Time'. Astrobiology 5, 415-438 (2005).

3. Pavlov, A. A. \& Kasting, J. F. Mass-Independent Fractionation of Sulfur-Isotopes in Archean Sediments: Strong Evidence for an Anoxic Archean Atmosphere. Astrobiology 2, (2002).

4. Kump, L. R. The rise of atmospheric oxygen. Nature 451, 277-278 (2008).

5. Harada, M., Tajika, E. \& Sekine, Y. Transition to an oxygen-rich atmosphere with an extensive overshoot triggered by the Paleoproterozoic snowball Earth. Earth Planet. Sci. Lett. 419, 178-186 (2015).

6. Ward, L. M., Kirschvink, J. L. \& Fischer, W. W. Timescales of Oxygenation Following the Evolution of Oxygenic Photosynthesis. Orig. Life Evol. Biosph. 46, 51-65 (2016).

7. Holland, H. D. Volcanic gases, black smokers, and the great oxidation event. Geochim. Cosmochim. Acta 66, 3811-3826 (2002).

8. Bekker, A. \& Holland, H. D. Oxygen overshoot and recovery during the early Paleoproterozoic. Earth Planet. Sci. Lett. 317-318, 295-304 (2012).

9. Campbell, I. H. \& Allen, C. M. Formation of supercontinents linked to increases in atmospheric oxygen. Nat. Geosci. 1, 554-558 (2008).

10. Earth Planet. Sci. Lett. 217, 237-244 (2004).

11. Kump, L. R. \& Barley, M. E. Increased subaerial volcanism and the rise of atmospheric oxygen 2.5 billion years ago. Nature 448, 1033-1036 (2007).

12. Hao, J., Knoll, A. H., Huang, F., Hazen, R. M. \& Daniel, I. Cycling phosphorus on the Archean Earth: Part I. Continental weathering and riverine transport of phosphorus. Geochim. Cosmochim. Acta 273, 7084 (2020).

13. Farquhar, Bao \& Thiemens. Atmospheric influence of Earth's earliest sulfur cycle. Sci. (New York, NY) 289, 756-759 (2000).

14. Johnston, D. T. Multiple sulfur isotopes and the evolution of Earth's surface sulfur cycle. EarthScience Rev. 106, 161-183 (2011).

15. Lyons, J. R. Mass-independent fractionation of sulfur isotopes by isotope-selective photodissociation of SO2. Geophys. Res. Lett. 34, 1-5 (2007).

16. Guo, Q. et al. Reconstructing Earth's surface oxidation across the Archean-Proterozoic transition. Geology 37, 399-402 (2009).

17. Bekker, A. et al. Atmospheric Sulfur in Archean Komatiite-Hosted Nickel Deposits. Science (80-). 326, 1086-1089 (2009). 
18. Bucholz, C. E., Biasi, J. A., Beaudry, B. P. \& Ono, S. Sulfur isotope behavior during metamorphism and anatexis of Archean sedimentary rocks: a case study from the Ghost Lake batholith, Ontario, Canada. Earth Planet. Sci. Lett. (2020).

19. Bucholz, C. E., Stolper, E. M., Eiler, J. M. \& Breaks, F. W. A Comparison of Oxygen Fugacities of Strongly Peraluminous Granites across the Archean-Proterozoic Boundary. J. Petrol. 59, 2123-2156 (2018).

20. Valley, J. W. et al. 4.4 billion years of crustal maturation: Oxygen isotope ratios of magmatic zircon. Contrib. to Mineral. Petrol. 150, 561-580 (2005).

21. Taylor, H. P. The effects of assimilation of country rocks by magmas on $180 / 160$ and $87 \mathrm{Sr} / 86 \mathrm{Sr}$ systematics in igneous rocks. Earth Planet. Sci. Lett. 47, 243-254 (1980).

22. Page, F. Z. et al. Zircons from kimberlite: New insights from oxygen isotopes, trace elements, and Ti in zircon thermometry. Geochim. Cosmochim. Acta 71, 3887-3903 (2007).

23. Savin, S. M. \& Epstein, S. The oxygen and hydrogen isotope geochemistry of clay minerals. Geochim. Cosmochim. Acta 34, 25-42 (1970).

24. Spencer, C. J. et al. Paleoproterozoic increase in zircon $\delta 180$ driven by rapid emergence of continental crust. Geochim. Cosmochim. Acta 257, 16-25 (2019).

25. Liebmann, J. et al. Emergence of continents above sea-level influences composition of sediment melts. Submitt. to EPSL (2020).

26. Spencer, C. J. et al. Proterozoic onset of crustal reworking and collisional tectonics: Reappraisal of the zircon oxygen isotope record. Geology 42, 451-454 (2014).

27. Valley, J. W., Bindeman, I. N. \& Peck, W. H. Empirical calibration of oxygen isotope fractionation in zircon. Geochim. Cosmochim. Acta 67, 3257-3266 (2003).

28. Pidgeon, R. T., Nemchin, A. A. \& Whitehouse, M. J. The effect of weathering on U-Th-Pb and oxygen isotope systems of ancient zircons from the Jack Hills, Western Australia. Geochim. Cosmochim. Acta 197, 142-166 (2017).

29. Chappell, B. W. \& White, A. J. R. I- and S-type granites in the Lachlan Fold Belt. Earth Environ. Sci. Trans. R. Soc. Edinburgh 83, 1-26 (1992).

30. Frost, B. R. \& Frost, C. D. A Geochemical Classification for Feldspathic Igneous Rocks. J. Petrol. 49, 1955-1969 (2008).

31. Percival, J. A. et al. Tectonic evolution of the western Superior Province from NATMAP and Lithoprobe studies. Can. J. Earth Sci. 43, 1085-1117 (2006).

32. Zhao, G. \& Zhai, M. Lithotectonic elements of Precambrian basement in the North China Craton: Review and tectonic implications. Gondwana Res. 23, 1207-1240 (2013).

33. Parra-Avila, L. A., Baratoux, L., Eglinger, A., Fiorentini, M. L. \& Block, S. The Eburnean magmatic evolution across the Baoulé-Mossi domain: Geodynamic implications for the West African Craton. Precambrian Res. 332, 105392 (2019). 
34. Väisänen, M., Mänttäri, I., Kriegsman, L. M. \& Hölttä, P. Tectonic setting of post-collisional magmatism in the Palaeoproterozoic Svecofennian Orogen, SW Finland. Lithos 54, 63-81 (2000).

35. Valley, J. W., Chiarenzelli, J. R. \& McLelland, J. M. Oxygen isotope geochemistry of zircon. Earth Planet. Sci. Lett. 126, 187-206 (1994).

36. Vielzeuf, D. Oxygen isotope heterogeneities and diffusion profile in composite metamorphicmagmatic garnets from the Pyrenees. Am. Mineral. 90, 463-472 (2005).

37. Hollis, J. A. et al. Low $\delta 180$ zircon grains in the Neoarchean Rum Jungle Complex, northern Australia: An indicator of emergent continental crust. Lithosphere 6, 17-25 (2014).

38. Flament, N., Coltice, N. \& Rey, P. F. The evolution of the $87 \mathrm{Sr} / 86 \mathrm{Sr}$ of marine carbonates does not constrain continental growth. Precambrian Res. 229, 177-188 (2013).

39. Bindeman, I. N. et al. Rapid emergence of subaerial landmasses and onset of a modern hydrologic cycle 2.5 billion years ago. Nature 557, 545-548 (2018).

40. Farquhar, J. et al. Mass-Independent Sulfur of Inclusions in Diamond and Sulfur Recycling on Early Earth. Science (80-). 298, 2369-2372 (2002).

41. Paris, G., Adkins, J. F., Sessions, A. L., Webb, S. M. \& Fischer, W. W. Neoarchean carbonate-associated sulfate records positive 33 S anomalies. Science (80-). 346, 739-741 (2014).

42. Johnston, D. T., Farquhar, J. \& Canfield, D. E. Sulfur isotope insights into microbial sulfate reduction: When microbes meet models. Geochim. Cosmochim. Acta 71, 3929-3947 (2007).

43. Kaufman, A. J. et al. Late Archean Biospheric Oxygenation and Atmospheric Evolution. Science (80-.). 317, 1900-1903 (2007).

44. Spencer, C. J., Murphy, J. B., Kirkland, C. L., Liu, Y. \& Mitchell, R. N. Was the supercontinent cycle activated by a Palaeoproterozoic tectono-magmatic lull? Nat. Geosci. 11, 97-101 (2018).

45. Condie, K. C., O'Neill, C. \& Aster, R. C. Evidence and implications for a widespread magmatic shutdown for 250 My on Earth. Earth Planet. Sci. Lett. 282, 294-298 (2009).

46. 10.1073 /pnas. 2003090117

Warke, M. R. et al. The Great Oxidation Event preceded a Paleoproterozoic "snowball Earth". Proc. Natl. Acad. Sci. 202003090 (2020). doi:10.1073/pnas.2003090117

47. Kirschvink, J. L. \& Kopp, R. E. Palaeoproterozoic ice houses and the evolution of oxygen-mediating enzymes: the case for a late origin of photosystem II. Philos. Trans. R. Soc. B Biol. Sci. 363, 27552765 (2008).

48. Squire, R., Campbell, I., Allen, C. \& Wilson, C. Did the Transgondwanan Supermountain trigger the explosive radiation of animals on Earth? Earth Planet. Sci. Lett. 250, 116-133 (2006).

49. Chen, X. et al. Rise to modern levels of ocean oxygenation coincided with the Cambrian radiation of animals. Nat. Commun. 6, 7142 (2015).

50. Cox, G. M., Lyons, T. W., Mitchell, R. N., Hasterok, D. \& Gard, M. Linking the rise of atmospheric oxygen to growth in the continental phosphorus inventory. Earth Planet. Sci. Lett. 489, 28-36 (2018). 
51. Jones, C., Nomosatryo, S., Crowe, S. A., Bjerrum, C. J. \& Canfield, D. E. Iron oxides, divalent cations, silica, and the early earth phosphorus crisis. Geology 43, 135-138 (2015).

52. Gurnis, M. Large-scale mantle convection and the aggregation and dispersal of supercontinents. Nature 332, 695-699 (1988).

53. Bleeker, W. The late Archean record: A puzzle in ca. 35 pieces. Lithos 71, 99-134 (2003).

54. Eriksson, P. G. \& Condie, K. C. Cratonic sedimentation regimes in the ca. 2450-2000 Ma period: Relationship to a possible widespread magmatic slowdown on Earth? Gondwana Res. 25, 30-47 (2014).

55. Miller, K. G. et al. The Phanerozoic Record of Global Sea-Level Change. Science (80-.). 310, 12931298 (2005).

56. Breaks, F. W., Selway, J. B. \& Tindle, A. G. Fertile Peraluminous Granites and Related Rare-Element Pegmatites, Superior Province of Ontario. in Short Course Notes, Geological Association of Canada 1787-125 (2005).

57. Zhao, G., Wilde, S. A., Cawood, P. A. \& Lu, L. Tectonothermal history of the basement rocks in the western zone of the North China Craton and its tectonic implications. Tectonophysics 310, 37-53 (1999).

58. Lompo, M. Geodynamic evolution of the 2.25-2.0 Ga Palaeoproterozoic magmatic rocks in the ManLeo Shield of the West African Craton. A model of subsidence of an oceanic plateau. Geol. Soc. London, Spec. Publ. 323, 231-254 (2009).

59. Claesson, S., Bibikova, E., Bogdanova, S. \& Skobelev, V. Archaean terranes, Palaeoproterozoic reworking and accretion in the Ukrainian Shield, East European Craton. Geol. Soc. London, Mem. 32, 645-654 (2006).

60. Huhma, H. Sm-Nd, U-Pb, and Pb-Pb isotopic evidence for the origin of the early Proterozoic Svecokarelian crist in Finland. (Geological Survey of Finland, 1986).

61. Ehlers, C., Lindroos, A. \& Selonen, O. The late Svecofennian granite-migmatite zone of southern Finland-a belt of transpressive deformation and granite emplacement. Precambrian Res. 64, 295309 (1993).

62. Reed, J. C., Bickford, M. E., Premo, W. R., Aleinikoff, J. N. \& Pallister, J. S. Evolution of the Early Proterozoic Colorado province: Constraints from U-Pb geochronology. Geology 15, 861 (1987).

63. Hoffman, P. F. United Plates of America, The Birth of a Craton: Early Proterozoic Assembly and Growth of Laurentia. Annu. Rev. Earth Planet. Sci. 16, 543-603 (1988).

64. Yang, Q. et al. An evaluation of precision and accuracy of SIMS oxygen isotope analysis. Solid Earth Sci. 3, 81-86 (2018).

65. LaFlamme, C. et al. In situ multiple sulfur isotope analysis by SIMS of pyrite, chalcopyrite, pyrrhotite, and pentlandite to refine magmatic ore genetic models. Chem. Geol. 444, 1-15 (2016).

66. Baertschi, P. Absolute 180 content of standard mean ocean water. Earth Planet. Sci. Lett. 31, 341344 (1976). 
67. Ding, T. et al. Calibrated sulfur isotope abundance ratios of three IAEA sulfur isotope reference materials and V-CDT with a reassessment of the atomic weight of sulfur. Geochim. Cosmochim. Acta 65, 2433-2437 (2001).

68. Wiedenbeck, M. et al. Further characterisation of the 91500 zircon crystal. Geostand. Geoanalytical Res. 28, 9-39 (2004).

69. Black, L. P. et al. Improved $206 \mathrm{~Pb} / 238 \mathrm{U}$ microprobe geochronology by the monitoring of a traceelement-related matrix effect; SHRIMP, ID-TIMS, ELA-ICP-MS and oxygen isotope documentation for a series of zircon standards. Chem. Geol. 205, 115-140 (2004).

70. Li, X.-H. et al. Penglai Zircon Megacrysts: A Potential New Working Reference Material for Microbeam Determination of Hf-O Isotopes and U-Pb Age. Geostand. Geoanalytical Res. 34, 117-134 (2010).

71. Schmitt, A. K. et al. Oxygen isotopic heterogeneity in the Temora-2 reference zircon. (2019). doi:10.11636/Record.2019.004

72. Crowe, D. E. \& Vaughan, R. G. Characterization and use of isotopically homogeneous standards for in situ laser microprobe analysis of $34 \mathrm{~S} / 32 \mathrm{~S}$ ratios. Am. Mineral. 81, 187-193 (1996).

73. Whitehouse, M. J. Multiple Sulfur Isotope Determination by SIMS: Evaluation of Reference Sulfides for $\Delta 33 \mathrm{~S}$ with Observations and a Case Study on the Determination of $\Delta 36 \mathrm{~S}$. Geostand. Geoanalytical Res. 37, 19-33 (2013).

74. Sharp, Z. D. A laser-based microanalytical method for the in situ determination of oxygen isotope ratios of silicates and oxides. Geochim. Cosmochim. Acta 54, 1353-1357 (1990).

75. Valley, J. W., Kitchen, N., Kohn, M. J., Niendorf, C. R. \& Spicuzza, M. J. UWG-2, a garnet standard for oxygen isotope ratios: Strategies for high precision and accuracy with laser heating. Geochim. Cosmochim. Acta 59, 5223-5231 (1995).

76. Wingate, M. T. D. \& Kirkland, C. L. Introduction to geochronology information released in 2015. Geol. Surv. West. Aust. 5p (2015).

77. Stern, R. A., Bodorkos, S., Kamo, S. L., Hickman, A. H. \& Corfu, F. Measurement of SIMS Instrumental Mass Fractionation of Pb Isotopes During Zircon Dating. Geostand. Geoanalytical Res. 33, 145-168 (2009).

78. Steiger, R. H. \& Jäger, E. Subcommission on geochronology: Convention on the use of decay constants in geo- and cosmochronology. Earth Planet. Sci. Lett. 36, 359-362 (1977).

79. Claoue-Long, J. C., Compston, W., Roberts, J. \& Fanning, C. M. Two Carboniferous ages: a comparison of SHRIMP zircon dating with conventional zircon ages and 40Ar/39Ar analysis. in Time Scales and Global Stratigraphic Correlation (eds. Berggre, W. A., Kent, D. V, Aubrey, M. P. \& Hardenbol, J.) 3-21 (Society for Sedimentary Geology, Special publication 54, 1995).

80. Stacey, J. S. \& Kramers, J. D. Approximation of terrestrial lead isotope evolution by a two-stage model. Earth Planet. Sci. Lett. 26, 207-221 (1975).

81. Paton, C., Hellstrom, J., Paul, B., Woodhead, J. \& Hergt, J. Iolite: Freeware for the visualisation and processing of mass spectrometric data. J. Anal. At. Spectrom. 26, 2508 (2011). 
82. Bucholz, C. E. \& Spencer, C. J. Strongly peraluminous granites across the Archean-Proterozoic transition. J. Petrol. (2019). doi:10.1093/petrology/egz033

83. LaFlamme, C. et al. Investigating sulfur pathways through the lithosphere by tracing mass independent fractionation of sulfur to the Lady Bountiful orogenic gold deposit, Yilgarn Craton. Gondwana Res. 58, 27-38 (2018).

84. Luo, G. et al. Rapid oxygenation of Earth's atmosphere 2.33 billion years ago. Sci. Adv. 2, (2016).

85. Mikkola, P., Huhma, H., Heilimo, E. \& Whitehouse, M. Archean crustal evolution of the Suomussalmi district as part of the Kianta Complex, Karelia: Constraints from geochemistry and isotopes of granitoids. Lithos 125, 287-307 (2011).

86. Dan, W. et al. Paleoproterozoic S-type granites in the Helanshan Complex, Khondalite Belt, North China Craton: Implications for rapid sediment recycling during slab break-off. Precambrian Res. 254, 59-72 (2014).

87. Corfu, F., Stott, G. M. \& Breaks, F. W. U-Pb geoehronology and evolution of the English River Subprovince, an Archean low P-high T metasedimentary belt in the Superior Province. Tectonics 14, 1220-1233 (1995).

88. Percival, J. A. A regional perspective of the Quetico metasedimentary belt, Superior Province, Canada. Can. J. Earth Sci. 26, 677-693 (1989).

\section{Figures}




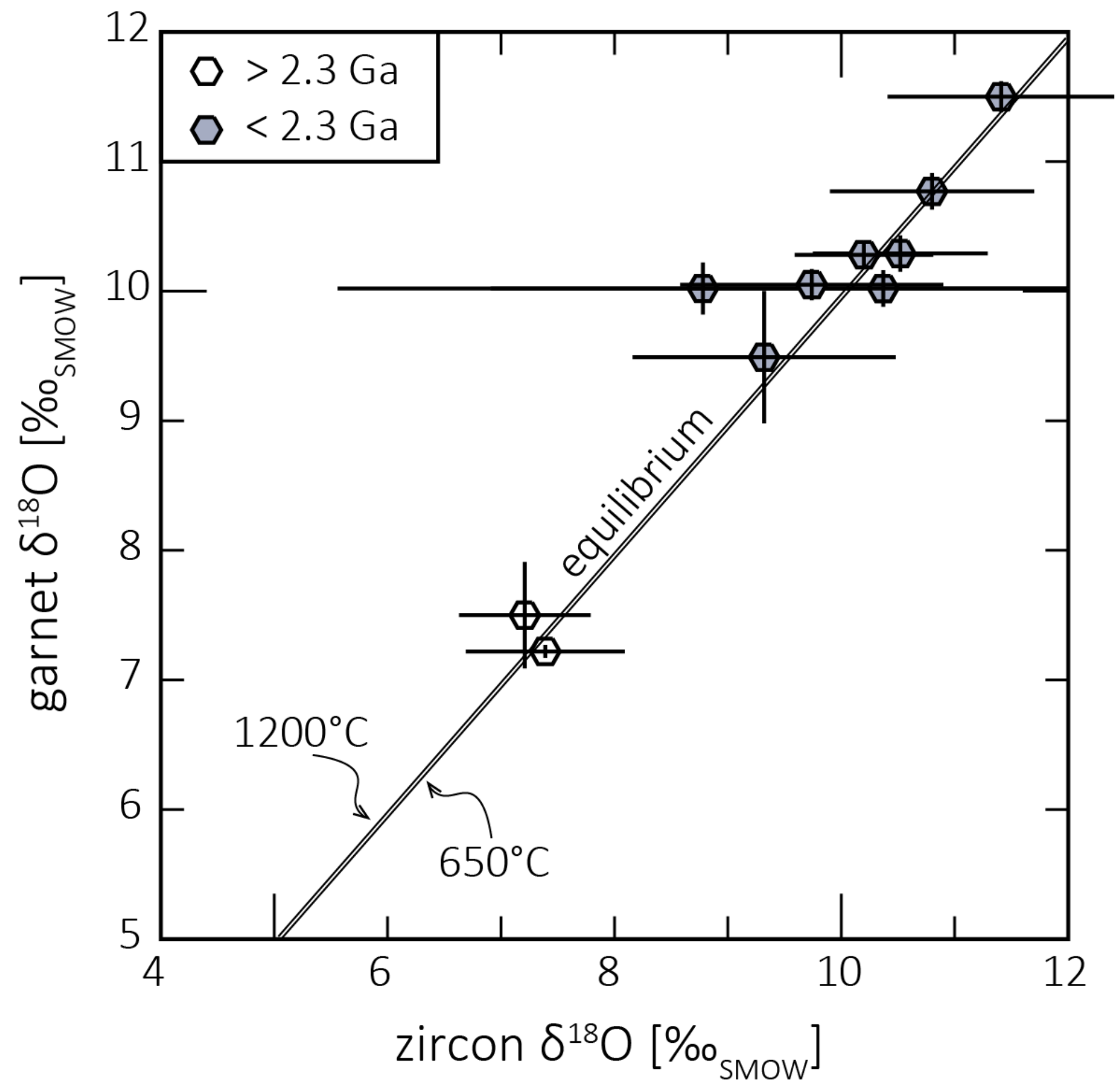

Figure 1

Zircon $\delta 180$ vs garnet $\delta 180$ color-coded by crystallization age of sediment-derived igneous rocks. Isotherms at $650^{\circ} \mathrm{C}$ and $1200^{\circ} \mathrm{C}$ are after 27 . Oxygen isotope data is shown as weighted averages. Single spot results of $\mathrm{O}$ isotope analysis are given in the appendix. Error bars are shown at $2 \sigma$ level. Note that large error bars for zircon $\delta 180$ are due to heterogeneity in these samples interpreted to be related to secondary processes (discussed in the text). 


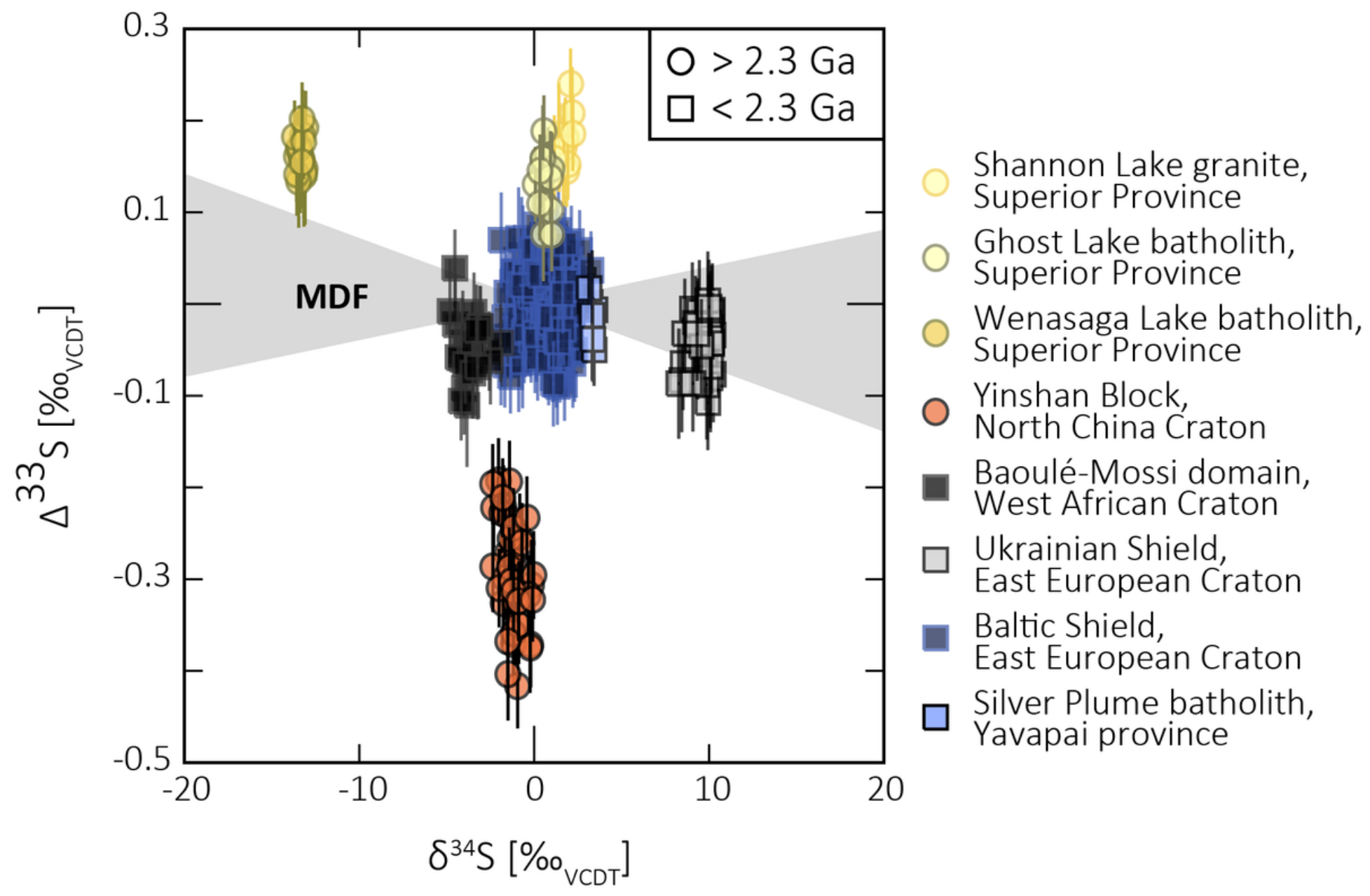

Figure 2

Single spot $\delta 34 S$ vs. $\Delta 33 S$ of sediment-derived igneous rocks. Error bars for $\Delta 33 S$ are shown at $1 \sigma$ level. Errors of $\delta 34 S$ at $2 \sigma$ level are smaller than the symbols. Grey area marks the range of $\Delta 33 S$ values that can be produced through mass-dependent fractionation processes 83 . Single spot results of sulfur isotope analysis are given in the appendix. 

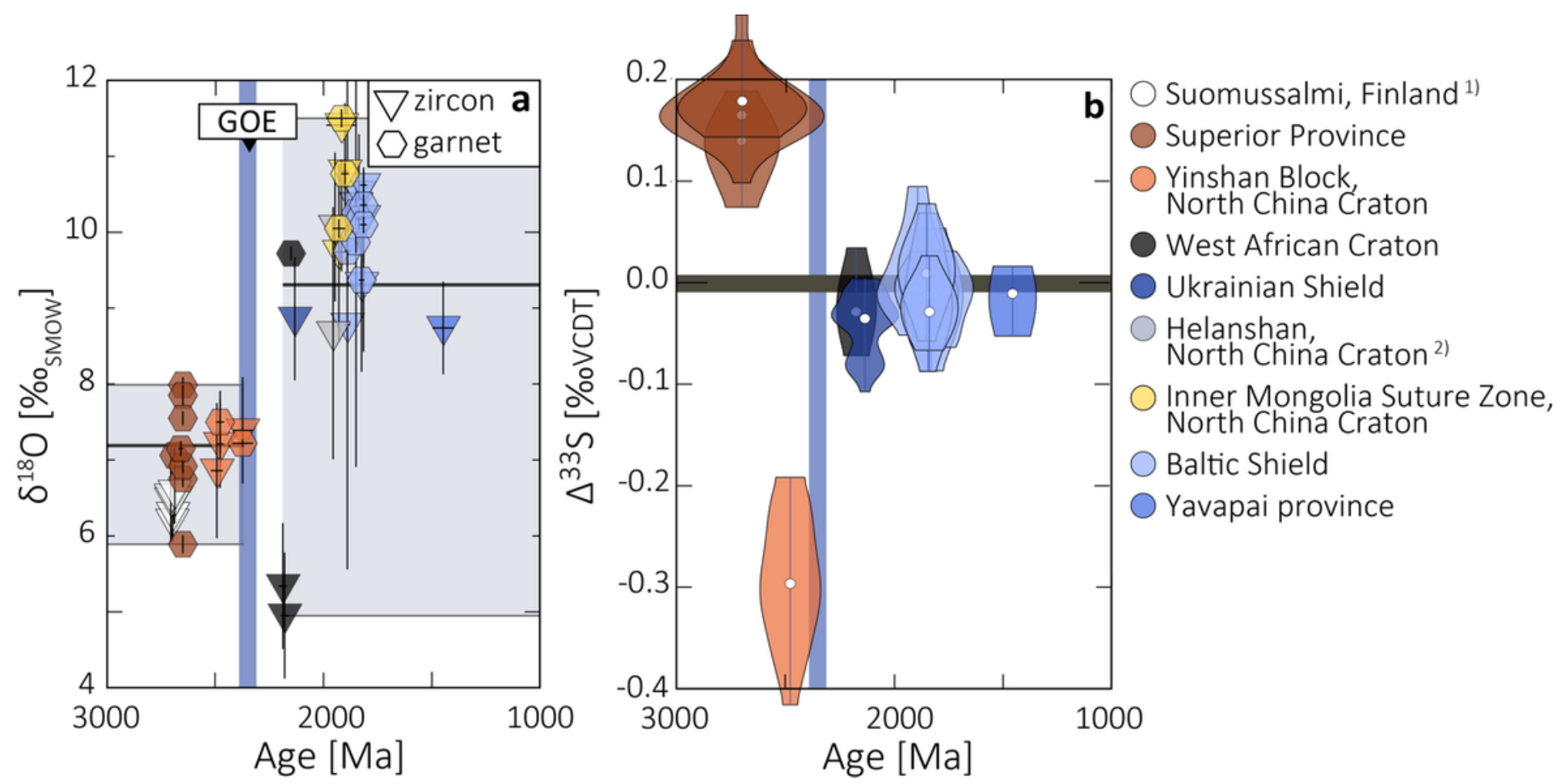

\section{Figure 3}

Oxygen and sulfur isotopic data vs. crystallization age of sediment-derived igneous rocks. Timing of atmospheric oxygenation 84 is shown as blue bar. Legend on the right applies to both parts of the figure. (A) Zircon and garnet $\delta 180$ vs. crystallization age of sediment-derived igneous rocks. Oxygen isotope data is shown as weighted averages. Grey bars mark average $\delta 180$ (as recorded by zircon and garnet) pre- and post-2.3 Ga, respectively. Single spot results of $O$ isotope analysis are given in the appendix. Error bars for oxygen isotope data and age are $2 \sigma$. Zircon oxygen isotope data from Suomussalmi and Helanshan are from 1)85, and 2)86. (B) Pyrite $\Delta 33$ S vs. crystallization age of sediment-derived igneous rocks shown as violin plots; white circles mark medians. Black bar marks $\Delta 33 S=0 \%$.

\section{Supplementary Files}

This is a list of supplementary files associated with this preprint. Click to download.

- SuppTableD1oxygen.xlsx

- SuppTablC1S.xlsx

- SuppTablB1UPb.xlsx

- SupplementaryMaterial.pdf 